\title{
Green orchid bee Euglossa dilemma Friese (Insecta: Hymenoptera: Apidae) ${ }^{1}$
}

Aaron Mullins ${ }^{2}$

\section{Introduction}

The orchid bees are all members of the family Apidae, and the tribe Euglossini, represented by five genera. Most are about the size of a honey bee, but are brightly colored with an iridescent metallic sheen. Typically, each species of orchid bee has a complex mutualistic relationship with a corresponding orchid in their native range. Orchids will produce scents that attract males of a particular species of bee that is the right size and shape to pollinate them. This relationship is not always chemical; some species of orchid go so far as to produce flowers that physically mimic a female bee as an attractant. Orchids will then affix a pollinarium to the bee which is carried to another orchid of the same species. All orchid bees are native to the New World tropics, from Mexico throughout Central and tropical South America. Specimens of one species of this group, Euglossa dilemma, commonly known as the green orchid bee, were collected in Broward County, Florida in 2003 by entomologists working with the USDA fruit fly monitoring program. This arrival was likely from a nest imported from Mexico concealed within a wooden structure such as a pallet. Originally considered to be Euglossa viridissima; Eltz et al. (2011) found the orchid bees in Florida to be Euglossa dilemma, a newly described cryptic sibling species of Euglossa viridissima.

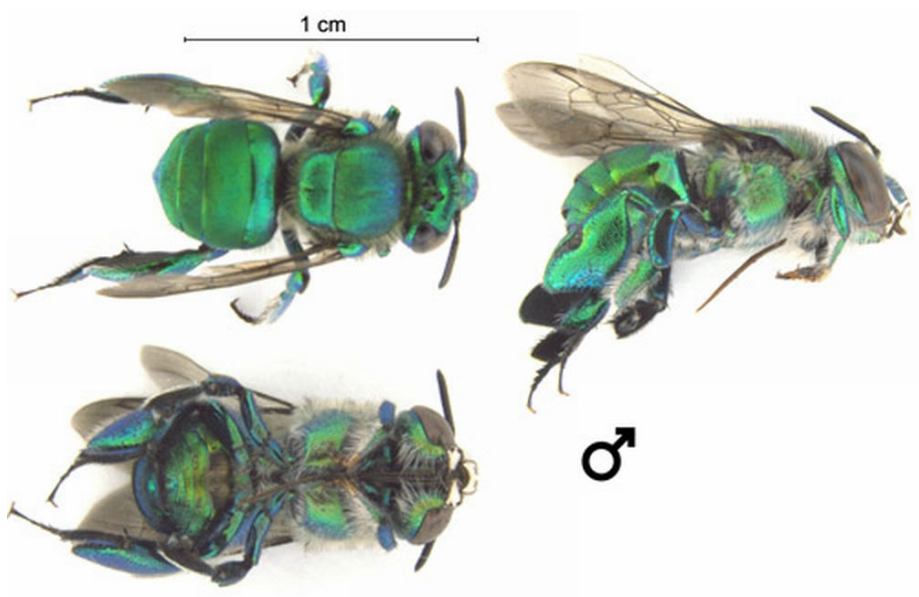

Figure 1. A male Euglossa dilemma photographed from various angles. Characteristic green metallic coloration, long tongue, brush-like front tarsi, and enlarged hind tibiae are visible.

Credits: Aaron Mullins, University of Florida, Ft. Lauderdale Research and Education Center

\section{Distribution}

Since this arrival, the green orchid bee has become well established in South Florida. Current reports of this species are mostly from Broward, Palm Beach, and Dade Counties. However its future distribution has been predicted to include almost half of peninsular Florida. Following a line that runs from Tampa to West Palm Beach and south, the potential range extends to the entire southern tip of the Florida Peninsula.

1. This document is EENY576, one of a series of the Entomology and Nematology Department, UF/IFAS Extension. Original publication date October 2013. Visit the EDIS website at http://edis.ifas.ufl.edu.

2. Aaron Mullins, senior biological scientist, Ft. Lauderdale Research and Education Center, UF/IFAS Extension, Davie, FL $33314-7719$. 


\section{Description}

Green orchid bees are a quite conspicuous and charismatic species. This is mostly due to their large size and bright metallic-green coloration (Fig.1). They are roughly the same size to slightly smaller than a honey bee, usually about $1.3 \mathrm{~cm}$ in length. The wing membranes are darkened, but transparent. Green orchid bees are very fast and agile flyers, and can be seen quickly darting from flower to flower separated by long periods of hovering. As with most bees in Florida, females possess a stinger and males do not. Although females can sting, they are quite timid in doing so. The sting itself is less painful than that of a honey bee, though unlike honey bees they can sting repeatedly.

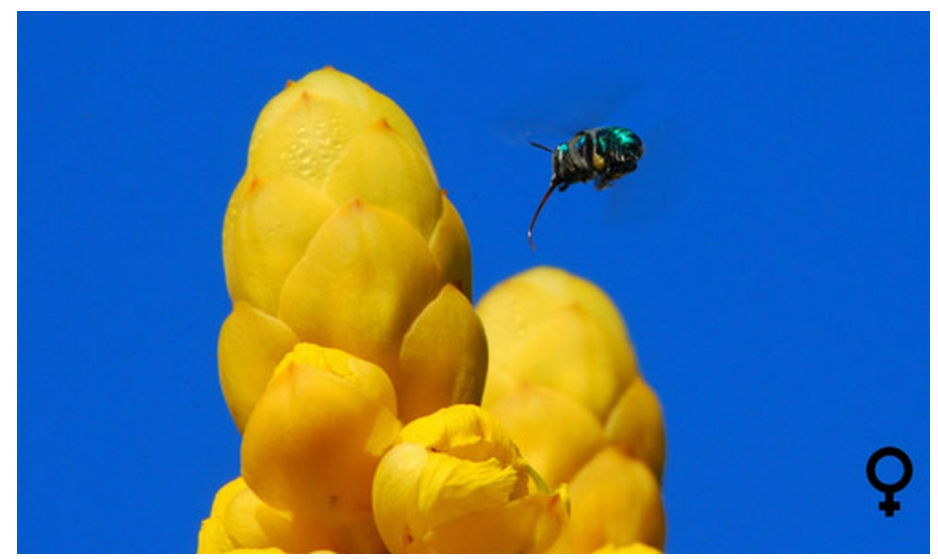

Figure 2. A female Eugloss a dilemma photographed while foraging. Corbiculae (pollen baskets) are visible, and contain yellow pollen stores.

Credits: Thomas Chauvenc, University of Florida, Ft. Lauderdale Research and Education Center

Green orchid bees are most likely to be confused with metallic members of the bee family Halictidae (sweat bees). However, orchid bees can easily be identified by their long tongues, which are roughly two thirds as long as their bodies. In contrast, sweat bees have quite short tongues in comparison to their bodies. Female orchid bees have corbiculae (pollen baskets) on their hind legs, in which they store collected pollen in order to provision their young (Figs. 2, 3b, 3c). Though males lack corbiculae, they have characteristic enlarged hind tibiae (Fig. 3a). These unusual structures have a hole on the outer side, which provides access to the spongy compartment within. These unusual structures play an important role in the storage of fragrant, aromatic compounds which male orchid bees collect from their environment.

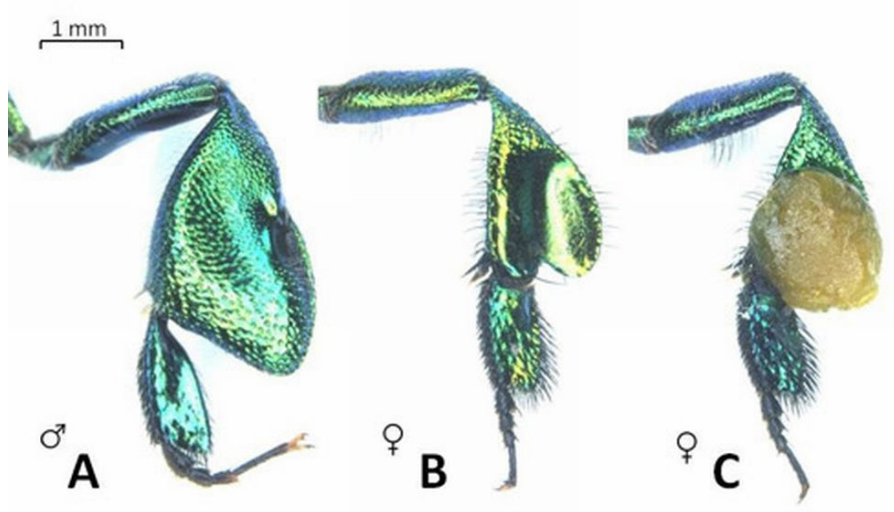

Figure 3. Hind legs of male (a) and female (b,c) green orchid bees. Male bees have an enlarged hind tibia with a hole providing access to the spongy compartment which acts as storage for fragrant compounds collected from its environment. Females have corbiculae (pollen baskets) for collecting pollen and propolis (plant resins). Credits: Aaron Mullins, University of Florida, Ft. Lauderdale Research and Education Center

\section{Nesting Behavior}

Though closely related to highly social bees in the same family, orchid bees are primarily solitary, showing only primitively social characteristics such as occasionally sharing communal nesting locations. Females construct nest cells out of propolis (resins collected from plant sources) (Fig. 4b). Nests are located in any sort of enclosed cavity;

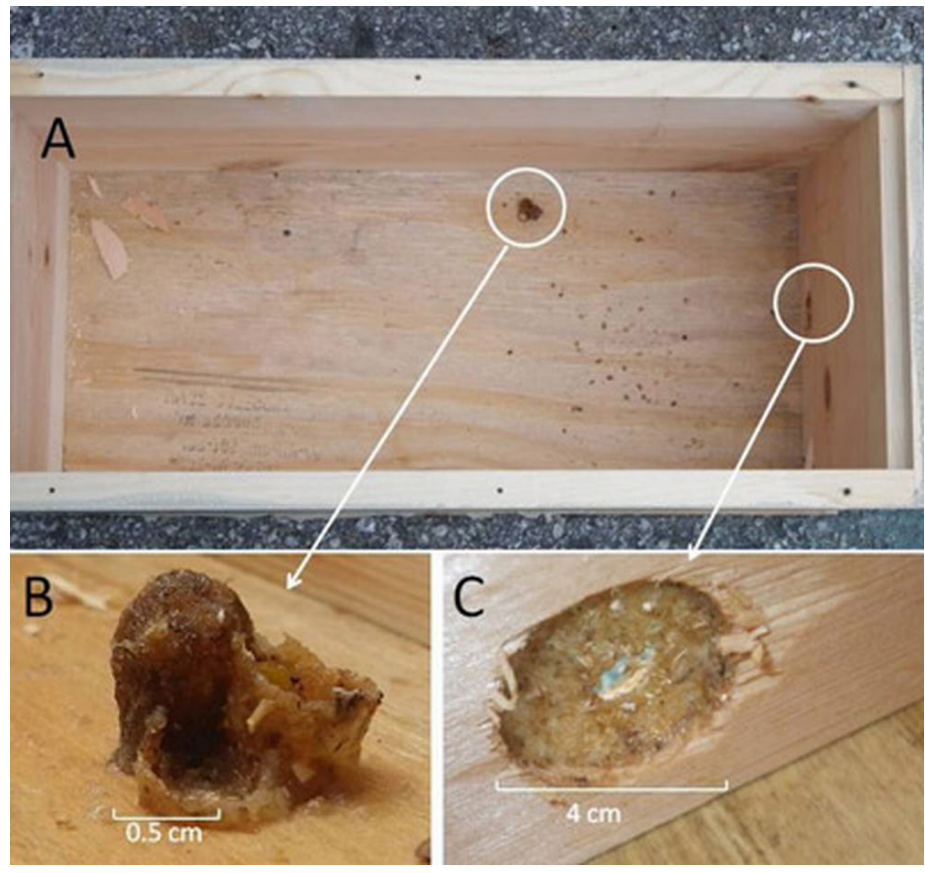

Figure 4. A young orchid bee nest constructed inside an empty nucleus colony box (a beekeeping hive box half as wide as a typical hive box used for housing small honey bee colonies) (a). The top has been removed revealing three cells under construction by a female green orchid bee (b). The entrance has been sealed off with propolis (plant resins) except for a small hole allowing entry for the female bee (c).

Credits: Aaron Mullins, University of Florida, Ft. Lauderdale Research and Education Center 
entrances are often sealed off with resin and plant debris (Fig. 4a, 4c). Mature nests can contain up to 20 cells. The young are provisioned with nectar and pollen provided by the mother as they develop.

\section{Male Behavior}

Male orchid bees exhibit a peculiar behavior of collecting fragrant volatile compounds from their environment. These compounds are meticulously collected, stored, and (presumably) presented to females by fanning their wings and "spray ventilating" their bouquet for the inspection of prospective mates. Fragrant compounds are collected by males with mop-like protrusions on their front tarsi (Fig. 3a, Video 1). They are then transferred into the enlarged hind tibiae through the hole. Collecting a complex bouquet of fragrances and storing them within the hind tibia represents a considerable investment on the part of male orchid bees. Fighting and robbing fragrance stores from competing males has been observed in nature. Different species of orchid bee tend to be quite particular in the fragrances sought.

This behavior is presumably what has led to the complex interaction with species-specific orchids in their native ranges. A particular orchid will provide fragrant compounds attractive to a specific species of orchid bee. In turn, the bees provide pollination of the orchid species. The arrival and success of the green orchid bee into Florida without its natural mutualistic orchid has provided evidence that the mutualism is perhaps obligatory on the part of the orchid, but merely facultative for the bees. In Florida, male green orchid bees are attracted to chemicals produced by certain wood-rot fungi (Video 1), decomposing vegetation, perfume flowers, and certain essential oils such as clove and cinnamon oil. Male green orchid bees can be quickly and easily attracted and observed by soaking a small piece of paper with clove oil and placing it outside.

Video 1. These are males of the green orchid bee (Euglossa dilemma), a neotropical orchid bee recently introduced into South Florida. The males of this species spend considerable time collecting fragrant, volatile compounds produced by wood decay fungi, other decomposing materials, and certain fragrant flowers. This footage was taken on January 25, 2012 on a structure in Flamingo Gardens, Broward County, Florida. The bees seem particularly interested in an old, decomposing piece of pinewood siding rife with wood decay fungi. The piece of siding also suffered damage from foraging by the eastern subterranean termite (Reticulitermes flavipes). Video by Aaron Mullins, University of Florida, Ft. Lauderdale Research and Education Center.

\section{Role as Pollinators}

All bees play an important role in the pollination of plants. In the case of green orchid bees, this role is not entirely known in its naturalized range in Florida. Pemberton and Wheeler (2006) provide a comprehensive list of important plants known to be visited by Euglossa dilemma in Florida. Though most of these plants are beneficial, there is evidence that the green orchid bee outperforms native bees in the pollination of certain invasive weeds.

\section{Selected References}

Aquino-Vázquez A, Cuadriello-Aguilar JI. 1990. Un nido de Euglossa viridissima Friese 1899 (Hymenoptera: Apidae: Euglossini), pp. 117-118B In XXV Congreso Nacional de Entomologíá. Programa y resumenes. Oaxaca, Oaxaca, Mexico.

Bembé B. 2004. Functional morphology in male euglossine bees and their ability to spray fragrances (Hymenoptera, Apidae, Euglossini). Apidologie 35: 283-291.

Carvalho Filho FS. 2010. Scent-robbing and fighting among male orchid bees, Eulalema (Apeulalema) nigrata Lepeletier, 1841 (Hymenoptera: Apidae: Euglossini). Biota Neotropica 10: 405-408.

Dressler RL. 1967. Pollination by euglossine bees. Evolution 22: 202-210.

Eltz T, Fritzsch F, Petch JR, Zimmermann Y, Ramirez SR, Quezada-Euan JG, Bembe B. 2011. Characterization of the orchid bee Euglossa viridissima (Apidae: Euglossini) and a novel cryptic sibling species by morphological, chemical, and genetic characters. Zoological Journal of the Linnean Society 163: 1064-1076.

Hinojosa-Díaz IA, Feria-Arroyo TP, Engel MS. 2009. Potential distribution of orchid bees outside their native range: The cases of Eulaema polychroma (Mocsáry) and Euglossa viridissima Friese in the USA (Hymenoptera: Apidae). Diversity and Distributions 15: 421-428.

Liu H, Pemberton RW. 2009. Solitary invasive orchid bee outperforms co-occurring native bees to promote fruit set of an invasive Solanum. Oecologia 159: 515-525.

Pemberton RW, Wheeler GS. 2006. Orchid bees don't need orchids: evidence from the naturalization of an orchid bee in Florida. Ecology 87: 1995-2001. 
Skov C, Wiley J. 2005. Establishment of the Neotropical orchid bee Euglossa viridissima (Hymenoptera: Apidae) in Florida. Florida Entomologist 88: 225-227.

Wiley J. 2004. Entomology Section. Insect Detection.

Euglossa sp., orchid bee. Triology 43 (3). 